\title{
Some Application of Microalgae in Sewage Treatment, there Availability and Sampling Protocol up to Conservation with Factor Encounter
}

\author{
Damtew Etisa*, Roman Nega and Woinshet Lule \\ Ethiopian Biodiversity Institute, Ethiopia
}

*Corresponding author: Damtew Etisa, Microbial Biodiversity Directorate, Ethiopian Biodiversity Institute, P.O. Box 30726, Addis Ababa, Ethiopia.

Received Date: August 20, 2018

Published Date: August 27, 2018

\begin{abstract}
To treat municipal wastewater effected from different sources of product, toilet, industry in most cases use microorganisms which requires a constant supply of oxygen, which is expensive and requires intense operations, energy input, manpower, and expertise. So, to reduce this much effort we can use to treat Growing microalgae in the ponds and tanks where the treatment is carried out is a good alternative solution to this problem since algal growth and photosynthesis will release substantial amounts of oxygen. At the same time the microalgae will remove nutrients (nitrogen and phosphorus). Microalgae are a diverse range of single celled primary producers and are found practically everywhere where there is light and humidity at least at some time of the year. The most important groups of microalgae in terms of abundance are green algae (Chlorophyceae), diatoms (Bacillariophyceae), blue-green algae (Cyanophycean) and golden algae (Cryophyte). The total estimated number of algae species are 200000 to 800 000, of which 35000 are described in literature. Microalgae can be identified depending up on their phylum, color, shape presence of flagella or absence, motility or not, typical morphology and the others of biological aspects such as chlorophyll type and organic content in technological way. To sample and transport to laboratory first know the chemistry of the fresh water sampled, consider factors to sample, put plot on each sampling point, mention the factors looking for and answer why? Question keep sampling material neat, sample without contaminant in proper manner and transport to laboratory is a good way to day. All most factors encountered during microalgae growth are: Contaminations, PH (Acidity or Alkalinity), temperature, total dissolved solid, Conductivity, salinity, aeration etc..
\end{abstract}

Keywords: Microalgae; Municipal wastes; Treatment

\section{Introduction}

Municipal wastewater is one of the main sources of surface water pollution. Ideal treatment includes three stages. Secondary treatment using microorganisms requires a constant supply of oxygen, which is expensive and requires intense operations, energy input, manpower, and expertise. Growing microalgae in the ponds and tanks where the treatment is carried out is a good alternative solution to this problem since algal growth and photosynthesis will release substantial amounts of oxygen. At the same time the microalgae will remove nutrients (nitrogen and phosphorus), incorporating them into biomass and thus carrying out tertiary treatment of the wastewater before it is released into the environment [1]. Microalgae's are of great significance since they comprise the major portion of primary producers in the aquatic environment. Temporal variability in the structure and function of phytoplankton community is of fundamental importance to the metabolism of an aquatic system. Aquatic environments are subject to high temporal variability, with the frequent reorganization of the relative abundance and species composition of phytoplankton as a result of the interactions between physical, chemical and biological variables. Phytoplankton abundance and distribution are strongly dependent on factors such as ambient nutrient concentrations, the physical state of the water column, and presence of grazers or herbivorous zooplankton [2]. Even though microalgae have potential to sequester different heavy metals and west product micronutrients there is difficulty of microalgae identification and characterization. There are at least 30,000 known species of microalgae. Microalgae are defined as photosynthetic cells mostly 
unicellular, although some complex associations give colonies with larger structures. This is a very heterogeneous group comprising prokaryotic organisms similar to bacteria (cyanobacteria, also called blue green algae) and eukaryotic organisms, such as diatoms [3]. The number of blue-green species is very large and probably not fully explored. Organic and inorganic substances which were released into the environment as a result of domestic, agricultural and industrial water activities lead to organic and inorganic pollution. The normal primary and secondary treatment processes of these wastewaters have been introduced in a growing number of places, in order to eliminate the easily settled materials and to oxidize the organic material present in wastewater. The final result is a clear, apparently clean effluent which is discharged into natural water bodies. This secondary effluent is, however, loaded with inorganic nitrogen and phosphorus and causes eutrophication and more long-term problems because of refractory organics and heavy metals that are discharged. Microalgae culture offers an interesting step for wastewater treatments, because they provide a tertiary bio treatment coupled with the production of potentially valuable biomass, which can be used for several purposes. Microalgae cultures offer an elegant solution to tertiary and quandary treatments due to the ability of microalgae to use inorganic nitrogen and phosphorus for their growth. And, for their capacity to remove heavy metals, as well as some toxic organic compounds, therefore, it does not lead to secondary pollution. In the current review we will highlight on the role of micro-algae in the treatment of wastewater.

The most sustainable way of growing microalgae for biofuel would be to utilize wastewaters derived from municipal, agricultural and industrial services. Microalgae effectively utilize carbon dioxide through photosynthesis and take up nutrients like nitrogen and phosphorous from the water. Microalgae cultivation in wastewater simultaneously produces valuable biomass at the same time as it reduces eutrophication of natural water bodies. Remediation of wastewaters with microalgae is an environmentally safe and economical way of wastewater treatment [4,5]. Microalgae were cultivated in wastewater from three different points in the wastewater treatment process. The first point is after the presedimentation pond, the second is after the sedimentation pond and the third is effluent that is about to be dispatched to the sea. The water collected after the presedimentation pond (W1), might be the best choice for cultivation of Scenedesmus dimorphous, when restricting the cultivation time to 14 days or less. Scenedesmus dimorphous is a freshwater unicellular microalga which belongs to Chlorophyta phylum. It grows rapidly at range of 0.8 day-1to 1.6 day-1and synthesize considerable number of desirable products such as protein and lipid. In its biomass Scenedesmus dimorphous contains $35 \%$ protein, $60 \%$ carbohydrate or $37 \%$ total lipid and tolerant to wide range of PH from 6.5-8, high gas of carbon dioxide, nitric oxide, sulphur dioxide concentration and remove ammonia and phosphorous in agro industrial waste water [6].

\section{Some of the current challenges in wastewater treatment are:}

I. Wastewater effluent typically has high concentrations of ammonia and phosphorus, which can lead to toxicity and eutrophication in surface waters.
II. Advanced wastewater treatment processes necessary for the removal of nutrients require additional biological or chemical processes which increase the use of chemicals, energy needs, and sludge quantities that need to be treated and disposed of. This substantially increases the cost of treatment.

III. Treatment plants have extensive energy needs, mainly due to the aeration of wastewater for aerobic biological treatment, which results in a large carbon footprint for the treatment plant.

IV. Disinfection byproducts formed after the disinfection of wastewater with chlorine-based disinfectants.

\section{a. This all problem improved by microalgae}

Microalgae can improve the wastewater treatment by:

I. Removing ammonia and total nitrogen from wastewater effluent.

II. Removing phosphorus from wastewater effluent.

III. Decreasing the aeration requirements, $\mathrm{CO}_{2}$ emission and carbon footprint of treatment plants.

IV. Decreasing the overall cost of treatment by including a simpler and sustainable treatment option.

V. Decreasing the pathogen content in the final effluent without the use of chemicals.

VI. Decreasing sludge quantities.

VII. Producing microalgae biomass that is a source for many useful products including biogas and biofuel.

\section{b. The biology of microalgae}

Microalgae consist of a wide mix of photosynthesizing organisms. Depending on morphology and size, algae are divided into micro- and macroalgae. Macro-algae are multiple cell organisms that resemble plants, while microalgae are a diverse range of single celled primary producers. Microalgae are found practically everywhere where there is light and humidity at least at some time of the year. Microalgae are found in marine and fresh waters, deserts, hot springs and on snow and ice. The number of species of microalgae is greatest in the seas and lakes [7,8]. Microalgae are categorized in divisions based on their characteristic form and structure, and specific structural, chemical and functional features. The most important groups of microalgae in terms of abundance are green algae (Chlorophyceae), diatoms (Bacillariophyceae), bluegreen algae (Cyanophycean) and golden algae (Cryophyte). The total estimated number of algae species are 200000 to 800000 , of which 35000 are described in literature [8]. Algae are considered to account for more than half of the primary production and use of carbon dioxide on our planet, and they have a very important role on the climate. The oxygen in our atmosphere origins from photosynthesizing blue-green algae (cyanobacteria). In addition, algae play an important role as a base for different nutrient chains in the environment. Algae utilize a lot of different nutrients and play a fundamental role in the circulation of macronutrients like nitrogen and phosphorous [7]. 


\section{c. Sampling protocol (Freshwater microalgae sampling protocol)}

To sample this microalga from different fresh water source of Ethiopia we have to consider the following criteria:

1. Know the chemistry, setup of the lake/reservoir/other fresh water you want to collect sample.

2. Collect information's about the freshwater you want to collect samples from concerned bodies and community around there.

3. Set up your sampling equipment's, samplers, cars, time frame of collection, objective of the sample will be collected etc.

4. After you reach the place of sample collection lake consider the factors you have to consider to sample the samples such as; near the lake inlet, near the lake outlet, center (buoy),flood area, agricultural area, animal intervention area, human intervention area(washing cloth, creation of dams, Runoff from agricultural and urban areas, Overuse, Pollution Runoff, municipal sewage plants and livestock operations release etc.), free intervention area(protected or forest dominated area or the other)

Note: the above factors are constant factors we always consider but there are some variable factors such as wind below direction, bird flock dominant etc.

5. If the lake you sample is not large enough separate the lake in equal length to sample but if it is very large

A. First consider major factors of catchment area such as agricultural area, direction, protected area, non-protected area, and etc.

B. Depending up on the major factor you mentioned above classify the major factor into subsample again into fragment.

6. Prepare your sample vials for sampling the sample from the factors you will design.

Note: All your sampling equipment should be sterile at any time you want to sample the samples.

7. At regular intervals (On-site testing) record dissolved oxygen concentration $(\mathrm{mg} / \mathrm{l})$, Specific conductivity $(\mu \mathrm{mhos} / \mathrm{cm})$, Sec chi Depth. (20 cm diameter black-white disk) to measure transparence, etc. are measured immediately in or/near the lake. but you can measure $\mathrm{P}^{\mathrm{H}}$, DO, Tc in laboratory alternatively

8. Open cork screw of bottles/vials by your right hand and don't touch by your hands inside the cork and hold the vials by your left hand take the sample three times from the same position to sample perfect sample and It is important to note that the collected microalgae should be kept in nutrient solution to keep them alive and to allow them to grow. Then close the vials by its cork screw and label the vial with full information.

9. All the necessary details should be recorded on the labels of sample bottles and again on field data sheet prepared by samplers in proper manner

10. If necessary preserve there some samples will be concentrated to $20 \mathrm{ml}$, preserved in $10 \%$ buffered formalin
(10 ml conc. formalin; $4.0 \mathrm{~g} \mathrm{NaH}_{2} \mathrm{PO}_{4}, \mathrm{H}_{2} \mathrm{O} ; 6.50 \mathrm{~g} \mathrm{Na}_{2} \mathrm{HPO}_{4}$ and volume made to $100 \mathrm{ml}$ with distilled or deionized water), if not put in ice box and transported to the laboratory for identification.

11. After reach laboratory store in refrigerator/dark place to reduce photosynthetic reaction

\section{d. Making composite sample in laboratory}

Make composite sample depend on factors you considered. For microscope identification, for aerator culturing, for other analysis.

\section{General Short comings of Microalgae Culture and Identification Factors}

\section{Contaminations}

Using axenic, i.e., only one species containing cultures with no infection of bacteria, fungi or viruses, cultures would be ideally for the mentioned experiments. However, since most oceanic organisms are not cultivable in axenic cultures, influences of contaminants may influence the experimental results. Especially through their fast growth virus replication may be critical. However, as studies on such influences on biodiversity - ecosystem functioning effects were not conduced, yet it is unknown how and to which degree such contaminants will affect the functioning of the communities compared to the monocultures containing the same contaminations. If the included strains stem from the same environment such influences may be negligible since all organisms were faced to the contaminants previously. Further, seen a strain as consortium, i.e. a combination of different organisms, may be one way to deal with this problem. Additionally, this can be studied by cross-experiments combining all species under study with each other and the observation of the development of bacterial or fungi growth or virus infections (Bastian S 2014).

\section{$\mathrm{P}^{\mathrm{H}}$ (Acidity or Alkalinity)}

The water $\mathrm{pH}$ value is determined by the relative concentrations of $\mathrm{H}+$ ion and $\mathrm{OH}$ - ion. Water with a $\mathrm{pH}$ of 7 has equal concentrations of $\mathrm{H}+$ ion and $\mathrm{OH}$ - ion and is considered to be a neutral solution. If a solution is acidic $\left(\mathrm{p}^{\mathrm{H}} 7\right)$, the concentration of $\mathrm{H}+$ ion is less than the concentration of $\mathrm{OH}$ ion. In this study, the $\mathrm{pH}$ value of the lake water is found to be slightly alkaline with the range of $9.43-9.45$ and $9.30-9.43$ in dry and wet seasons, respectively. The mean $\mathrm{pH}$ values between both seasons showed no significant difference. The $\mathrm{p}^{\mathrm{H}}$ values measured in both seasons were found above the upper limit defined by WHO guide lines 6.5- 8.5 [9]. The $\mathrm{p}^{\mathrm{H}}$ was found to have slight variations between stations and seasons. Higher $\mathrm{pH}$ may result due to waste discharge, microbial decomposition of organic matter in the water body or may be attributed to sewage discharge by surrounding human population. Rainfall generally has a $\mathrm{pH}$ value of 5 to 6.5 which is acidic because of dissolved carbon dioxide and air pollutants such as Sulphur dioxide or nitrogen oxides. If rainwater flows over soil containing hard water minerals, its $\mathrm{pH}$ usually increases. Bicarbonate ions, $\mathrm{HCO}_{3}^{-}$, resulting from limestone deposits react with water to produce $\mathrm{OH}$ - ions according to the reaction given:

$$
\mathrm{HCO}_{3}-+\mathrm{H}_{2} \mathrm{O}-\mathrm{H}_{2} \mathrm{CO}_{3}-+\mathrm{OH}
$$


This results in lakes often being basic with $\mathrm{p}^{\mathrm{H}}$ values between 7 and 8 , sometimes as high as 8.5. The measure of $\mathrm{p}^{\mathrm{H}}$ is very important indication of the quality of water due to the sensitivity of organisms to the $\mathrm{p}^{\mathrm{H}}$ of their environment. Small changes in $\mathrm{p}^{\mathrm{H}}$ can affect the existence of biological life and most of them thrive in a quite narrow and critical $\mathrm{pH}$ range.

\section{Temperature}

Temperature is one of the important factors in aquatic environment since it regulates the physicochemical as well as the biological activities. Shade is important to the health of the water body as it reduces the warming effect of direct sunlight. This may cause by some human activities removed shade trees from the area, allowing more sunlight to reach the water, causing temperature to rise. Temperature of air above the water body may affect water temperature depending on the depth of the water. Shallow water bodies are more susceptible to temperature changes than deep water. The increment in the lake water temperature will affect solubility of dissolved oxygen. More gas can be dissolved in cold water than warm; therefore, animals requiring a high level of dissolved oxygen will only thrive in cold water. Increased water temperature can cause an increase in the photosynthetic rate of aquatic plants and algae, which can lead to increased plant growth and algal blooms, and harm the local ecosystems, Metabolic rate of organisms and Resistance in organisms if water becomes too hot or too cold, organisms become stressed, lowering their resistance to pollutants, diseases and parasites [9] Table 1.

Table 1: Major divisions of freshwater algae: microscopically appearance.

\begin{tabular}{|c|c|c|c|c|c|}
\hline $\begin{array}{l}\text { Algal division } \\
\text { (phylum) }\end{array}$ & Index of Bio diversity & Typical color & $\begin{array}{l}\text { Typical morphology } \\
\text { of freshwater species }\end{array}$ & $\begin{array}{l}\text { Motility (Vegetative } \\
\text { Cells/Colonies) }\end{array}$ & Typical example \\
\hline $\begin{array}{l}\text { 1.Blue-green algae } \\
\text { (Cyanophyta) }\end{array}$ & 297 & Blue-green & $\begin{array}{l}\text { Microscopic or visible } \\
\text { - usually colonial }\end{array}$ & $\begin{array}{l}\text { Buoyancy regulation } \\
\text { some can glide }\end{array}$ & $\begin{array}{c}\text { Cylindrospermopsis, } \\
\text { Microcystis }\end{array}$ \\
\hline $\begin{array}{l}\text { 2. Green algae } \\
\text { (Chlorophyta) }\end{array}$ & 992 & Grass-green & $\begin{array}{c}\text { Microscopic or } \\
\text { visible - unicellular or } \\
\text { filamentous colonial }\end{array}$ & $\begin{array}{l}\text { Some unicells and } \\
\text { colonies with flagella }\end{array}$ & $\begin{array}{l}\text { Chlamydomonas, } \\
\text { Scenedesmus sp. } \\
\text { Chlorella }\end{array}$ \\
\hline $\begin{array}{l}\text { 3. Euglenoids } \\
\text { (Euglenophyta) }\end{array}$ & 124 & Various colors & $\begin{array}{l}\text { Microscopic- } \\
\text { unicellular }\end{array}$ & Mostly with flagella & Euglena, Phacus \\
\hline $\begin{array}{l}\text { 4.Yellow-greenalgae: } \\
\text { (Xanthophyta) }\end{array}$ & 73 & Yellow-green & $\begin{array}{l}\text { Microscopic - } \\
\text { unicellular or } \\
\text { filamentous }\end{array}$ & $\begin{array}{c}\text { Flagellate zoospores } \\
\text { and gametes }\end{array}$ & Ophiocytium, Vaucheria \\
\hline $\begin{array}{l}\text { 5. Dinoflagellates } \\
\text { (Dinophyta) }\end{array}$ & 54 & Red-brown & $\begin{array}{l}\text { Microscopic- } \\
\text { unicellular }\end{array}$ & All with flagella & Ceratium, Peridinium \\
\hline $\begin{array}{l}\text { 6. Cryptomonads } \\
\text { (Cryptophyta) }\end{array}$ & 15 & Various colours & $\begin{array}{l}\text { Microscopic- } \\
\text { unicellular }\end{array}$ & Mostly with flagella & $\begin{array}{l}\text { Rhodomonas, } \\
\text { Cryptomonas }\end{array}$ \\
\hline $\begin{array}{l}\text { 7. Chrysophytes } \\
\text { (Chrysophyta) }\end{array}$ & 115 & Golden brown & $\begin{array}{c}\text { Microscopic - } \\
\text { unicellular or colonial }\end{array}$ & Some with flagella & Mallomonas, Dinobryon \\
\hline $\begin{array}{c}\text { 8. Diatoms } \\
\text { (Bacillariophyta) }\end{array}$ & 1652 & Golden brown & $\begin{array}{l}\text { Microscopic - } \\
\text { unicellular or } \\
\text { filamentous colonies }\end{array}$ & $\begin{array}{l}\text { Gliding movement on } \\
\text { substrate }\end{array}$ & Navicula, Aulacoseira \\
\hline $\begin{array}{l}\text { 9. Red algae } \\
\text { (Rhodophyta) }\end{array}$ & 22 & Red & $\begin{array}{c}\text { Microscopic or } \\
\text { visible - unicellular or } \\
\text { colonial }\end{array}$ & Non-motile & $\begin{array}{c}\text { Batrachospermum, } \\
\text { Bangia }\end{array}$ \\
\hline $\begin{array}{l}\text { 10. Brown algae } \\
\text { (Phaeophyta) }\end{array}$ & 2 & Brown & $\begin{array}{c}\text { Visible - multicellular } \\
\text { cushions and crustose } \\
\text { thalli }\end{array}$ & Non-motile & $\begin{array}{l}\text { Pleurocladia, } \\
\text { Heribaudiella }\end{array}$ \\
\hline
\end{tabular}

\section{Total Dissolved Solids (TDS)}

Solids are found in streams in two forms, suspended and dissolved form. Dissolved solids in freshwater samples include soluble salts that yield ions such as sodium $(\mathrm{Na}+)$, calcium $\left(\mathrm{Ca}^{2+}\right)$, magnesium $\left(\mathrm{Mg}^{2+}\right)$, bicarbonate $\left(\mathrm{HCO}_{3}\right)$, sulfate $\left(\mathrm{SO}_{4-2}\right)$, or chloride (Cl-). The TDS concentration in a body of water is affected by many different factors. Dissolved solids may originate from a variety of organic and inorganic sources that can be either natural or human derived, such as the degradation of rock or plant matter or agricultural runoff of topsoil. A high concentration of dissolved ions is not, by itself, an indication that a stream is polluted or unhealthy. It is normal for water bodies to dissolve and accumulate high concentrations of ions from the minerals in the rocks and soils over which they flow. High levels of TDS in water used for drinking purposes may lead to many diseases. As deposits contain salts $(\mathrm{NaCl}$ and $\mathrm{KCl})$ or limestone $\left(\mathrm{CaCO}_{3}\right)$, significant concentrations of $\mathrm{Na}+, \mathrm{K}+, \mathrm{Cl}-$ will result, as well as hard-water ions, such as $\mathrm{Ca}^{2+}$ and $\mathrm{HCO}^{3-}$ from limestone. TDS is sometimes used as a "watchdog" environmental test and its values will change when ions are introduced to water from salts, acids, bases, hard-water minerals, or soluble gases that ionize in solution. There are many possible man-made sources of ions that may contribute to elevated TDS readings. Fertilizers from fields can add a variety of ions to a stream. Increases in TDS can also result from runoff from roads that have been salted in the winter. TDS values in lakes and streams are typically found to be in the range of 50 to $250 \mathrm{mg} / \mathrm{L}$ but in areas of especially hard water or high salinity, TDS values may be $500 \mathrm{mg} / \mathrm{L}$ or higher [10]. 


\section{Conductivity}

Conductivity is a measure of water's capability to carry an electric current and also it is a tool to assess the purity of water. Minerals and salts must be dissolved in water in order for it to conduct electricity; as the concentration of dissolved solids increases, so does the conductivity of the liquid. The high conductivity of the lake is also attributable to increased ionic concentration due to evaporative water lose. The wide variations in the conductivity values between seasons could be attributed to the combined influence of sea water intrusion with the flooding tide and influence of fresh water particularly during the rainy season. The variation between the stations is suggestive for the influence on the lake while the seasonal differences observed for the conductivity which is a clear indication of the role of season in the ionic distribution in the lake [10].

\section{Salinity}

Microalgae has its own system to adjust salinity range. Generally, seawater microalgae can tolerate higher salinity rather than fresh water microalgae [11]. Studies showed that microalgae has its own optimal growth salinity, when salinity higher or lower than this will be harmful to algal growing rate. For example, when in the low salinity growing condition, it will be helpful for algal growth with the addition of $\mathrm{NaCl}$ and $\mathrm{NaSO} 4$ but when the salinity higher than $6 \mathrm{~g} / \mathrm{L}$, the growth rate of microalgae will be prohibited [12].

\section{Aeration}

Aeration of cultures serves to keep microalgae in suspension, to supply the carbon needed for growth in equal portion. Aeration agitatesthegrowth medium and thisgives ahomogenousdistribution of algal cells throughout the vessel for adequate exposure to illumination. The microalgae growth was the illumination, since constant circulation kept the algal cells in suspension, thus allowing them to receive the same amount of light exposing as much surface area as possible to the light, promoting the photosynthesis, and consequently, better growth and characteristic green coloration. Mixing is the most practical way to dilute radiation evenly to all cells in the culture, improving the light regime [13-15].

\section{Conclusion}

Know a day's environmental pollution and the problem of natural management take into consideration in our environment and atmosphere because of different industrial's leak effluents to environment and cause imminent amount of health status environmental corruption through heavy metals accumulation cause cancers, animals feed and drink effluent cause fatal, humans inhale and cause bronchitis, cancers, anorexia, fatigue, sterility etc. therefore using biological aspect and mitigate such like problem may be the solution to our environment. Even though microorganisms have paramount in reduction of waste product through oxygen supply and expensive one we have to prefer microalgae growth in the pond and reduce pollution and nutrient availability. Because Microalgae can improve the wastewater treatment by: Removing ammonia and total nitrogen from wastewater effluent, Removing phosphorus from wastewater effluent, Decreasing the aeration requirements, $\mathrm{CO}_{2}$ emission and carbon footprint of treatment plants, Decreasing the overall cost of treatment by including a simpler and sustainable treatment option, Decreasing the pathogen content in the final effluent without the use of chemicals, Decreasing sludge quantities, Producing microalgae biomass that is a source for many useful products including biogas and biofuel.

\section{References}

1. Enawgaw Y, Lemma B (2018) Phytoplankton community composition and nutrient conditions as an indicator of ecosystem productivity in lake Tinishu Abaya, rift valley, Ethiopia. Int J Fisheries Aquat Stud 6(3): 173186.

2. Reynolds CS (1990) Temporal scales of variability in pelagic environments and the response of phytoplankton. J Freshwater Biol 23(1): 25-53.

3. Randrianarison G, Ashraf MA (2017) Microalgae: a potential plant for energy production. J Geology Ecol Landscapes 1(2): 104-120.

4. Christenson L, Sims R (2011) Production and harvesting of microalgae for wastewater treatment, biofuels and bioproducts. Biotechnol Adv 29(6): 686-702.

5. Pittmana JK, Deana AP, Osundeko O (2011) The potential of sustainable algal biofuel production using wastewater resources. Bioresour Technol 102(1): 17-25.

6. Ren T (2014) Primary factors affecting growth of microalgae optimal light exposure duration and frequency". Graduate Theses and Dissertations: 13793.

7. Lindholm T (1998) Algfenomen och algproblem. Åbo: Åbo Akademi.

8. Rajkumar R, Zahira Y (2013) The biology of microalgae. In biotechnological applications of microalgae: biodiesel and value added products 7-15 edn CRC Press, USA.

9. WHO (2008) Guidelines for drinking water quality, $3^{\text {rd }}$ edn, Geneva, Switzerland.

10. National Service Center for Environmental Publications (NSCEP) (1988) National water quality inventory 1988 Report to Congress. Washington DC, USA.

11. Zhu M, Zhang X, Mao Y (2003) Effects of temperature, salinity and illumination on the growth of Thalassiosira sp. Mar Sci 27(12) 58-61.

12. Liu C, Sun H, Zhu L (2006) Effects of salinity formed with two inorganic salts on freshwater algae growth. Acta Scientiae Circumstantiae 26(1): 157-161.

13. Cohen Z (1999) Chemicals from microalgae. $1^{\text {st }}$ edn, CRC Press, USA, pp. 419.

14. John et al, (2002) A Biodiversity: number of species of freshwater and terrestrial algae, adapted from Sigee et al. freshwater algae: identification and use as bioindicators, pp. 5-7.

15. Steudel B (2014) Microalgae in ecology: ecosystem functioning experiments. J Oceanography Mar Sci 2: 122. 